Social Inquiry: Journal of Social Science Research

2020, Vol. 2, No. 2, pp. 279-301

https://doi.org/10.3126/sijssr.v2i2.33080

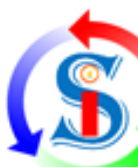

Article History: Received: 28 January 2020 | Revised: 12 September | Accepted: 16 October 2020

Original Article

\title{
Mediation Practices in Post-Conflict Situation in Nepal: The Way Forward
}

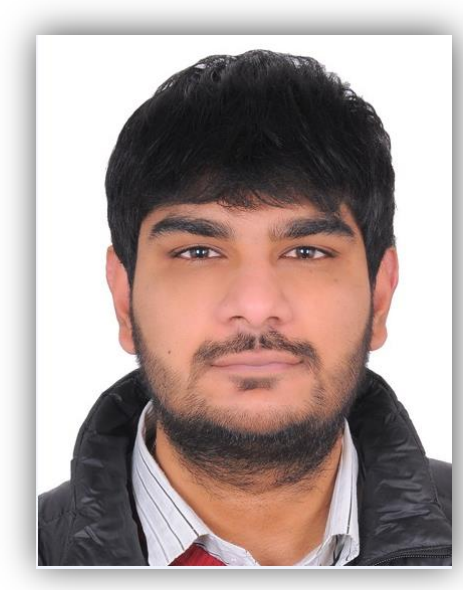

Sambid Bilas Pant

Independent Scholar, Kathmandu, Nepal

Email:sambypant@gmail.com

(iDhttps://orcid.org/0000-0001-7745-4332

Social Inquiry: Journal of Social Science Research, Volume2, Issue 2, 2020 


\section{Abstract}

This paper aims to critically examine the increasing role of community mediation in the post-conflict situation in Nepal. The practice of community mediation at the professional level is in a preliminary stage in Nepal. Regarding the peace settlement process and the state of community mediation in different countries, various efforts have been made in Nepal regarding community mediation. The country is gradually advancing towards community mediation practices in ensuring access to justice. Community mediation has been practiced for resolving disputes or conflict through the judicial committees (JCs) formed under the local government. The practices of conflicts or disputes resolution through community mediation have begun in Nepal at the individual or family level, school or community level, or at workplace. It is, therefore, vital to prevent the recurrence of conflicts or disputes through community mediation to ensure sustainable peace. Various efforts have been made to build the capacity of individuals and agencies to settle disputes and to ensure mutual trust and cooperation in Nepal. In the changing context, confronting COVID 19, building awareness, providing education and training to the mediators for community mediation is vital to execute JC practice in Nepal. Community mediation as an important aspect in ensuring sustainable peace in the spirit of the local government act is, therefore, very essential in Nepal.

Keywords: Capacity Building; Conflict; Dispute; Judicial Committee; Mediation; Resolution

\section{Introduction}

The Constitution of Nepal (CON) was promulgated through the constitutional assembly on 20th September 2015 to fulfil the aspirations of the nation for sustainable peace, good governance, development, and prosperity through the federal, democratic, republican system of governance (Ministry of Law, Justice \& Parliamentary Affairs, 2015). This constitution, which is committed to socialism based on democratic norms and values, has its roots in the decade long conflict which began due to a nationwide-armed struggle by the Communist Party of Nepal (Maoist) on 
13th February 1996 (Karki \& Seddon, 2003). The movement was aimed at establishing a new democratic republic and a new socialist society, to uproot semi-feudalism and to drive out monarchy (Karki \& Seddon, 2003). For achieving sustainable peace, a number of issues related to social, political, cultural, technological, economic, and other changes are yet to be achieved. To this end, new institutions and laws are in place in the country. Therefore, an indepth understanding of the terms conflict or dispute, conflict resolution, and community mediation and familiarity with the mediation practices for dispute resolution is essential.

\section{Understanding Conflict}

Conflict is a term that has wide connotations. It could be defined in various forms and levels like individual level, group level, and at the organizational level. According to Webster's dictionary, conflict can be defined as a debate or contest; a disagreement, argument, dispute, quarrel; a struggle, battle or confrontation; or a state of unrest, turmoil, chaos and violence (Merriam Webster, 2019). Conflict generally has negative connotations as it is opposite to cooperation and peace. Conflict is also defined as the state of clash of interests where there is the presence of an active stage of disagreement, where people extremely differ in opinions, principles and practices manifested in the forms of grievance, dispute and war.

In contemporary literature, conflict denotes the tension, hostility, competitiveness that exists among different groups in society. The struggle between disputants is aimed to obtain social resources and improve their positions in the social system. Generally, conflict is considered to be an inevitable and integral part of the social process. It is manifested within an individual, between individuals (a family, between families), among community members and social groups, between community groups and external organizations, between different castes and ethnic groups, between political parties and between countries, etc.

Society may face different forms of conflict, from minor disputes between neighbours to communal violence, religious riots and hooliganism. At the global level, conflict may take the form of revolution, wars, inter-state political rivalry, severe disagreement between at least two sides, and how the problems 
can be solved, e.g., solvability and its intensity.

Based on how the problems can be solved, e.g., solvability and its intensity Sparks' (1992) had defined three kinds of conflicts, a terminal conflict, a paradoxical conflict and a litigious conflict (Martinelli \& Almeida, 1998). Generally, a terminal conflict seems unsolvable by an agreement leading toward a "win-lose" conclusion; a paradoxical conflict leads to a "loselose" outcome having neither a "winwin" nor a "win-lose" conflict. The litigious conflict seems to be unsolvable but tends towards a "win-win" result (Martinelli \& Almeida, 1998).

The type of conflict (armed conflict) that evolved in Nepal could be termed as a terminal conflict that was resolved through a combination of reconciliation between political parties and a joint struggle against the then political regime. In this regard, the armed conflict in Nepal could be termed as the intra-state conflict with the use of arms and weapons. The common determinants of armed conflicts involve organized, armed groups, in most cases with the government as a party to the conflict.

\section{Understanding Mediation}

There are different types of disputes or conflicts at different levels, e.g., individual, family, community, regional and international levels. They might be related to personal growth and development, resource utilization, earning a livelihood, gender, gender identity, sexual orientation, religion, or disability. Conflict is an interactive and dynamic process and therefore, it is difficult for individuals or groups to make decisions and choose alternatives (Cyert \& March, 1963, as cited in Zhang, 2016).

Different techniques have since long been used for resolving conflicts. Dispute resolution techniques are very significant for managing the conflict efficiently and constructively transform it into peace. There are some notable techniques and skills such as negotiation, mediation, facilitation, arbitration, adjudication, diplomacy and litigation with the help of which we can resolve conflict. Mediation is a process through which disputants work together with the assistance of a neutral third party to assist disputing parties to resolve conflicts through face-to-face meetings (Ridley-Duff \& Bennett, 2010). 
Mediation as an alternative dispute resolution (ADR) mechanism, where the trained mediator uses the mediation skills, is gaining prominence in Nepal (Khadka, 2004, as cited in Dahal \& Bhatta, 2008, p. 20). Various shreds of evidence show that the justice system is very weak and inaccessible to the marginalized people and they have limited roles in resolving local disputes. Mediation is able to fill this void in judicial assistance by providing immediate, affordable, and locally accessible dispute resolution services. Mediation in Nepal offers a space to resolve interpersonal and collective disputes, which transforms adversarial tensions into cordial relationships based on mutual respect.

As of September 2013, Asia Foundation and its local partners have received over 22,400 mediation cases and have achieved a resolution rate of more than 85 percent (The Asia Foundation, 2013). Following the Mediation Act 2068 (2011), Village Development Committees and Municipalities may provide necessary technical service to community-based mediators to settle the dispute through community-based mediation (Nepal Law Commission, 2011). The Tol Sudhar Samitis (community reform committees) recognized by the Janajati, Dalit, Madheshi, women and indigenous groups to resolve disputes have shown that 74 percent of cases out of 689 cases from eleven districts have been settled through 1300 community mediators trained by civil society and NGO actors (Khadka, 2004, as cited in Dahal \& Bhatta 2008, p. 20). Whether it is at the individual, institutional or national level, mediation is a first preferred technique of conflict resolution. Generally, disputes within an organization are resolved through a formal process.

\section{Peace Process and Settlement of Conflict in Post Conflict Situation}

During decade long conflict in Nepal, over 13,000 people died and 1,300 went missing (Office of the High Commissioner for Human Rights, 2012) and 200,000 people were displaced; properties worth millions of dollars lost (Tiwari, 2007) and human rights violated. Following the signing of the 12-point understanding between the Seven Party Alliance and Communist Party of Nepal (Maoist) (hereafter refers to as Maoist) in February 2006 and the subsequent Comprehensive Peace 
Accord (hereafter refers to as CPA) signed in November 2006 provided a fundamental basis for ending a decade long armed conflict and restoring peace. Nepal has passed through drastic transformation and is facing newly emerging challenges in politics since.

As a major step towards establishing sustainable peace, the ending of the armed conflict and the power-sharing arrangements from November 2006April 10, 2008 was materialized by means of November 2006 CPA and the interim constitution signed between the Maoists and the Government of Nepal which was represented by the Seven Party Alliance of mainstream political parties (International Crisis Group, 2009).

Various measures were taken to have a peaceful political settlement after the end of a decade long conflict in Nepal. They include the declaration of a new constitution in 2015 after two elections of Constituent Assembly, integration of Maoist combatants into Nepal Army, formation of Truth and Reconciliation Commission (TRC) and the Commission of Investigation on Enforced Disappeared Persons (CIEDP) that were established in 2015 to investigate conflict-era rights violations
(The Record, 2018). Out of 19,600 fighters registered to the United Nations, only 1,460 joined the army. The rest were given a rehabilitation package of up to $\$ 10,200$ to lead civilian life (Sharma, 2013).

\section{Truth and Reconciliation}

\section{Commission}

In accordance with the Enforced Disappearances Enquiry, Truth and Reconciliation Commission Act, 2014, a five-member Truth and Reconciliation Commission was constituted by the Government of Nepal on February 10, 2015. The Commission has the mandate to act according to the functions, duties and powers of the commission stipulated in Section 13 of the Enforced Disappearances Enquiry, Truth and Reconciliation Commission Act, 2014(TRC, 2014). By Jan 2018, a total of 60,298 complaints of the victims were registered in the TRC and further were still to be reported (The Record, 2018). In addition, the CIEDP has handed over 410 files to the TRC's jurisdiction. By that time, the commissioners have completed a preliminary investigation of 827 cases only (The Record, 2018). 


\section{Commission of}

\section{Investigation on Enforced Disappeared Persons}

The CIEDP is a body formed by the Government of Nepal to investigate the cases about the persons who disappeared during the conflict between the state party and the then Nepal Communist Party (Maoist) between 13th February 1996 to 26th November 2006. According to the second interim report of the commission (CIEDP, 2017), in the commission, 232 cases were pending, 114 were merged cases after dual complaints and the report forwarded to TRC were 414. The TRC received around a total of 2306 cases. (185 female and 2116 male) (CIEDP, 2017).

\section{Community Mediation Practices in Different Countries}

Community mediation has been practiced all over the world for a long time. Mediation has been widely recognized globally as it is considered more flexible than other forms of dispute resolution techniques, specifically adjudication and court proceedings. It is also considered much faster, less expensive, more empowering and procedurally satisfying than the judicial system (Grange, 2014).

\section{Community Mediation in}

\section{Cambodia and EI Salvador}

Using the concept of the interplay between the national factions and the external interveners in peace negotiations, Lee (2011) examined the processes of the peace negotiations in Cambodia (1987-1993) and El Salvador (1989-1993) (Lee, 2011). The study was successful in exploring the process of negotiating actors' strategies and the pattern of the interplay between them (Lee, 2011). Lee (2011) used the terms 'interplay,' 'interaction,' and 'interrelation interchangeably between the actors in peace processes. This study has clearly indicated that the weaknesses that need to be addressed and the 'interplay between actors' are useful in unveiling the factors that contribute to a successful peace process (Lee 2011).

\section{Community Mediation in China and Korea}

Wall (1993) revealed that in both China and Korea, the mediators educate the disputants and more frequently argue 
for concessions. Further, the study revealed that during mediation, higher preference is given to societal goals than to the rights of either disputant (Wall \& Blum, 1991).

Conflict resolution in China has been changing over a period of time. The study by Wall and Blum (1991) focused on ninety-seven community mediators in the People's Republic of China, found both successful and unsuccessful mediations using twenty-seven mediation techniques. However, they utilized different techniques for couple and non-couple disputes (Wall \& Blum, 1991).

Based on the use of original surveys from Beijing and villages in six provinces and participant-observation research, mediation was found to be is fairly common in the countryside compared to the city. It was also found that those involved in rural governance and more women than men were interested in the use of mediation. Additionally, it revealed that mediation was rare in major cities like Beijing.

Generally, in rural areas, the people request for Mediation at the Villagers' Committees (VCs) level. In China, the people see mediations through
Residents' Committees (RCs) in cities such as Beijing and VCs in the countryside (Read \& Michelson, 2008). The mediation system among Chinese citizens provides a window on broader questions of the individual's relationship through the structure of institutions and culture (Read \& Michelson, 2008). The People's Republic of China has a long history of mediation in dispute resolution, and it was reported that the mediation handled 5 million cases in 2008. There were more than 800,000 peoples mediation commissions, and there were more than 4 million mediators in Mainland China (handling 80000 cases of people) (Chen, as cited in Lee, 2013). However, in Mainland China, there is also a provision of court mediation where the Judge plays the dual role of mediator and also the ultimate adjudicator (Hilmar, cited in Lee 2013). In the course of providing judge or mediation, Chinese Judges meet the disputants separately to settle the cases (Lee, 2013).

\section{Mediation Process in Hong Kong}

The mediation process in Hong Kong is different compared to Mainland China. The mediators do not play the role of 
adjudicative authority, and in Hong Kong, the mediator is a third party person who is trained and impartial. The mediator is selected to assist the disputants in reaching a voluntary agreement (Lee, 2013). In regards to settling the family and community disputes, the community mediation organizations play an active role in Hong Kong. Some non-government organizations like the Hong Kong Mediation Centre and the Hong Kong Family Welfare Centre play an important role in mediation. (Alexander, as cited in Lee, 2013).

\section{Community Mediation in Sri Lanka}

In Sri Lanka, research was conducted based on a desk review of literature on 'Theory of Change' approaches in international development (Valters, 2013) and generation of primary empirical data through semi-structured interviews with the staff of Centre for Mediation and Mediation Training (Valters, 2013). In Sri Lanka, as of January 2013, there were 309 community mediation boards coordinated by the state, mandated by law. There were over 7000 mediators. The mediators of the boards are engaged as volunteers and since 1991; these community mediation boards have mediated more than 2 million disputes (Siriwardhana, 2011, as cited in Valters, 2013). The disputes included both civil and criminal cases, while the most common issues were based on assault, loan cases and land issues. Community mediation has been gaining more recognition due to the inaccessibility of Sri Lanka's court system, post-war situation, and prevalence of considerable caste-based discrimination, gender-based discrimination, and violence. According to a recent foundation publication, Alternative Dispute Resolution has a rich tradition of mediation in Sri Lanka, which is one of the reasons for its popularity and acceptance today (Valters, 2013).

\section{Community Mediation in America, New Zealand and Australia}

The practice of community mediation is strong even today in America. There is an increasing number of referrals from the justice system to service centres in the United States (Berg, 2013, as cited in Zander, 2017). The practice of mediation beyond formal adjudication processes for resolving conflicts began in 1960 in America (Teresa, 2001, as cited in Zandar, 2017). This process 
involved moving away from political adjudication for resolving conflict and dispute resolution. This mediation process was favoured for the community, primarily considering the civil and political unrest featuring racial violence and dissatisfaction and the "dis-empowerment of black Americans (Hensler, 2003/04, as cited in Zandar, 2017).

As indicated in the New Zealand Law Commission, one of their aims is to provide the parties with an ability to resolve their issues in civil disputes before they come to court (Zander, 2017).Community mediation is also popular in New Zealand and it has been initiated by the state rather than the community itself. ADR is recognized in New Zealand as an integral part of the judicial system (Berg, 2013). Conflicts are referred to mediation through public institutions in areas such as employment and tenancy disputes. Without having a general mediation statute, the mediation provisions are in place into more than 60 statutes (Berg, 2013).

Under federal statute (the Community Justice Centres (Pilot Project) Act 1980), in New South Wales, a pilot community mediation project was established in January 1981 in accordance with America's example (Zander, 2017). Considering the successful experiences of the pilot program, this pilot program was extended in Sydney on a permanent basis through the Community Justice Centres Act 1983 and also similar service centres were rolled out in Adelaide and Victoria (Cameron, 1988, as cited in Zandar, 2017).

\section{Community Mediation Practices in Nepal}

At a time when there was no presence of local governments during the Maoist movement, the community mediation programme played crucial roles in the creation of local "socio-judiciary" institutions for promoting women's access to public life (De Voe \& Larkin, 2018). By blending human rights and social development agendas, various International organizations such as the USAID and TAF were involved in promoting justice and conflict resolution by providing funding and technical support for community mediation, particularly in rural areas. This encouraged Nepali NGOs to implement programmes targeting increasing women's power and participation (De Voe \& Larkin, 2018). 
Though the community mediation is in a very preliminary stage in Nepal, various local, indigenous trained mediators and Nepali society have since long been engaged in community mediation for providing education and raising awareness focusing on human rights (De Voe \& Larkin, 2018). Having ethnic and geographic diversity in the nation, a wide range of formal and informal justice systems prevail in resolving disputes (Amos et al., 2016). The traditional approaches include Gram Parishad (Village Council) Mukhiya, (village chief), Bichari (person knowledgeable on legal matters) and Pancha-Bhaladami (five elderly gentlemen) to mediate most of the local conflicts. Similarly, tamudhin (Gurung-ghar previously led by Mukhiya), Magar-Samaj (Magar society) and Thakali Samaj in Gandak region; Limbus developed Chumlung (an assembly in the eastern part of Nepal) Mullah (religious guru) are trusted for mediation in Muslims community and Chaudhary (community leader) have been evolved to mediate community disputes (Dahal \& Bhatta, 2008). Likewise, old institutions like the Mukhiya system in lower Mustang and Raja system (principality) in the upper Mustang also resolve local conflicts through customary laws (Dahal \& Bhatta, 2008).

Based on qualitative research, Pant (2019) revealed that elected Dalit women representatives were involved in resolving the disputes related to property ownership, the issue of irrigation canal, construction of roads, the encroachment of forest in the community, the issue of water sources and water taps. Considering the growing importance of the role of community mediators, he further emphasized the need for building the capacity of the NGO /CBOs working in conflict resolution by strengthening their financial and technical capacity (Pant, 2019)

With the support of donors and INGOs, many local and national NGOs are involved in mobilizing local civil society groups, local institutions, clubs, media persons, human rights groups, mothers groups, self-help groups, NGOs and Community-Based Organizations (CBOs). They provide opportunities to the people of different level like marginalized people, minority groups, and different ethnic groups, Madhesis, Muslims and the Dalits for resolving neighbourhood conflict in the absence of official means of resolution (Dahal \& 
Bhatta, 2008). The trained persons, such as the mediators or local volunteers serving as community mediators, are involved in resolving the disputes (Dahal \& Bhatta, 2008).

Upreti et al. (2010) have raised the issues of restorative justice and suggested the mediation between the victims and perpetrators towards reconciliation and social and political reintegration in post-conflict Nepal. Though the role of UNMIN was also criticized for lack of impartiality and independence on some sensitive issues of peace, it did play a commendable role in mediation and facilitation in this process in the Nepali peace process (Upreti et al., 2010).

During the time of conflict, The Asia Foundation (TAF) Nepal developed a 'Local Conflict Transformation Theory' towards its goal of improving justice and social harmony in the communities in rural Nepal. The TAF believed that the provision of community mediation services would contribute to improvements in social harmony at the local level, enhance an important state function through local collective action, and gradually improve state-society relations (Adhikari \& Stein, 2013).
A study conducted by Paul (1994)on the project implemented by the Asia Foundation in 1993 in 12 districts across Nepal found that being aware of the law or their legal rights, the local people seek justice or solutions to their disputes at the community level (Lederach \& Thapa, 2012). Following the Kaplan study, a pilot community mediation project was conducted in six districts and later in 1996. TAF, along with three Nepali NGO partners, redesigned the mediation component of the program in respective districts.

The constitution of Nepal 2015 has made provision of judicial committees (JCs) at each of the 753 municipalities and rural municipalities and the Local Government Operation Act (LGOA) 2017 was enacted to implement the provisions related to the powers of local levels as per the constitution (Nepal Law Commission, 2017). The JC aims to mediate between the disputants to convey the message of a win-win situation by ensuring the settlement of peace in the post-conflict situation. Before the institution of the Judicial Committee at the local government level, there were practices of dispute resolution through the community mediation process in Nepal. The successes of JCs, by and large, depend 
on the extent of community mediation on the issues of disputants. The success of community mediation will provide justice to the disputants and lead to the success of the Judicial Committees and that of women representatives in ensuring peace in post-conflict environments (The Kathmandu Post, 2018).

Under the LSGA, in September 2002, the TAF supported the Ministry of Local Development (MLD) in preparing and implementing comprehensive plans for a pilot program of local-level dispute resolution under the LSGA. The program was envisioned to increase access to justice for rural communities. With the support of US consultants, TAF, in cooperation with five Nepali NGOs, prepared training materials and conducted training of master trainers to launch community mediation across the 11 districts, expanding finally to 14 districts (Lederach \& Thapa, 2012). Indicating towards the use of participatory action research that was applied by local mediators and mediation program coordinators, Lederach and Thana (2012) revealed that the impact of participatory action research as a method to deepen the practice of mediation at the community level in rural Nepal (Lederach \& Thapa, 2012).

A research project 'Community Initiatives for Common Understanding' (CICU) carried out to map justice provision in the five CICU districts in Nepal revealed that marginalized groups have often been deprived of the formal justice system due to lack of access mainly because of cost, geography, language, complex and long bureaucratic procedures. A persistent lack of legal awareness and education prevent many marginalized individuals and groups from seeking and accessing justice (USAID, 2016).

In Nepal, besides considering community mediation as a tool to avoid the formal legal process, it has been considered as a process that brings equality and fairness to the disenfranchised. It offers quick, inexpensive, and equitable justice to those previously marginalized (De Voe \& Larkin, 2018). As a part of this activist process, the CMC members are trained in human rights and basic Nepali law. Their training emphasizes that they are working "for the betterment of society," and they are encouraged in their "feelings of equality and togetherness". This encourages 
everyone, the mediators and the local participants to be more sensitive to gender issues and to respect all mediators as leaders and public figures within their communities (De Voe \& Larkin, 2018). The Mainstreaming Gender Equity Programme, which assumes inequity in power and status between people, is a joint program of the Ministry of Women and Social Welfare and the United Nations. Its main objective is to increase women's access to justice and to establish women's rights (De Voe \& Larkin, 2018)

Paudel (n.d.) stresses the increasing role of Dalit women, social activists, politicians, volunteers and others to move beyond advocacy to heavily engage themselves in dispute settlement to increase social harmony through improved respect, communication, and cooperation between caste, class, and gender relations. It has also improved local governance through enhanced engagement between communities and local government bodies (The FriedrichEbert-Stiftung [FES], 2001).

The CBOs working in mediating conflict and building the capacity at the community level should concentrate their efforts on building the capacity of the members of the Judicial Committees. While there are a number of agencies involved in dispute resolution activities and building the capacities of various CBOs and NGOs, TAF has played a leading role in nurturing strengthened and sustainable community mediation programmes in Nepal. TAF since long has supported policy engagement on mediation at different levels- from national to community level, in involving policy formulation to coordination and networking, providing training and capacity building of various agencies involved in dispute resolution (The Asia Foundation).

In Nepal, the Mediation Act 2011 was authenticated and published on 9th May 2011 for the settlement of the dispute through community mediation, based on the procedure prescribed through mediation pursuant to this Act (Nepal Law Commission, 2011). From a high level of development, a common understanding about the legal dimensions and technical approaches to mediation and other ADR activities and coronation and networking with likeminded partner organizations and helping the GON to enact the 2010 Mediation Act has largely contributed to recognizing the validity and 
importance of community mediation within the Nepali context. TAF has played a lead role in drafting mediation regulations and the National Plan of Action on mediation in partnership with the Supreme Court and the Ministry of Law and Justice (The Asia Foundation).

FES Nepal office, established in 2001, has been involved in various activities with a sense of responsibility to support its partner organizations in peace efforts (FES, 2001). Seemingly, the foundation has built the capacity of an institutionallevel mediator network, Community Mediators' Society focusing on the information dissemination, sharing advocacy towards dispute resolution and developing the culture of dispute resolution, promoting peace and harmony in Nepali communities, and in protecting, promoting, and uniting the rights and interests of community mediators.

With goals of promoting and protecting economic, social, political, and development rights of Dalit and vulnerable groups various Dalit organizations, Nepal National Dalit Social Welfare Organization (NNDSWO) has been advocating the issues from human rights perspective (NNDSWO, n.d.). Lamsal (2012) noted that Dalit civil society organizations, which mushroomed with the restoration of democracy in 1990, have provided more space for identifying groups to organize, assert, formulate demands and instigate work to more explicitly increase the social, economic, and political powers of Dalits. Barron (2017), taking reference of the TAF's independent impacts and recovery monitoring (IRM) longitudinal research, concluded that earthquakes affected those of low caste. Barron further mentioned the challenges towards the recovery of Dalits and other low caste groups in earthquake-affected districts. The constitution of Nepal has guaranteed the right of Dalits in various forms. Provisions have been made in the constitution for free education with a scholarship from primary to higher education, technical and vocational education, health, and social security to the Dalit community (Constitution of Nepal, 2015). Concerning women's role in post conflict situation there is an increasing role of the government and civil society organization to recognize the crucial roles of women in policymaking and socioeconomic reforms. It is high time for Dalit women associated with policy-making, local political body, teaching or any other activities, human right organization and 
civil organizations to assist other women with social integration, psychological recovery, accessing economic opportunities, and attaining peace and security.

As a part of Community mediation, the contribution of Enabling State Programmes (ESP) to access to justice in Nepal started in 2001 in Nepal. However, a long-term strategy with programme support is required if community mediation is to be replicated and extended further (Adhikari \& Stein, 2013). In Nepal, there were Local Peace Committees (LPCs) in each village for resolving conflicts on a local level. In the absence of the LPCs, the government of Nepal has no effective plan to build the capacity of the mediators at the community level in the changing context.

\section{Mediation in School and Adult Education}

There is an increasing role of mediation in schools. These days the school has become a place full of conflict and considering the violation of their rights, the pupils and teachers react violently at the moment in a situation of the lack of concrete morality (Mic et al., 2014). It is believed that students are competent to resolve their own disputes and also develop listening, critical thinking, and problem-solving skills. At the school level, mediation is considered to be vital in resolving the disputes and personal growth and development of student skills such as listening, critical thinking, and problem-solving (Murray, 2003). School-based mediation is in the form of dialogue addresses the emotional and informational needs of the victims, and it is a dialogue-driven, with emphasis upon victim empowerment (Murray, 2003).

Mediation is such an interesting subject that is widely used in various walks of life. By learning and using mediation techniques, adults can be helped in many ways in solving daily problems and hurdles (Silvera, 2006). To enhance the trainees' strengths and newly discovered skills, there is a need for the training of mediators (Silvera, 2006).

Silvera (2006) mentions mediation is a profession, a vocation, which provides means of livelihood to a growing number of adults in many continents and countries and an economical procedure to settle rivalries, conflicts, misunderstandings in all walks of life (Silvera, 2006). As a result of the violence in the schools, educators these 
days have considered the study of conflict and conflict management as an urgent matter. In schools across America, mediation is considered to be one of the ways of conflict management (Keller \& Trevaskis, 1994). Most of the violence, interfering with productivity and the quality of life in schools and the community are the results of unresolved and lingering conflict (Keller \& Trevaskis, 1994). Obviously, there is a need for the schools to adopt various measures like counselling, improved interpersonal communication, and adopting various disciplinary actions.

\section{Enhancing the Role of Judicial Committees in Nepal}

The government has taken various measures to ensure the peace process by means of several measures like army integration and settlement of other critical issues through TRC and CIEDP. While performing the roles of the members of the judicial committees, each one should try to be neutral while resolving the disputes.

According to Linda (2000) while managing disputes, the mediators, like judges, claim to remain neutral in the course of managing disputes (Linda,
2000). We occasionally hear through the media that despite high expectations from the Local JCs to get justice in the disputes, the JCs have not been able to settle the dispute. Based on the case studies of five municipalities Budanilakantha, Mahalaxmi, Tokha, Dhulikhel, and Surya Binayak- within the Kathmandu Valley, Centre for Investigative Journalism, Nepal revealed that there had been an increased frustration among serviceseekers. There are several reasons, such as reluctance to accept the women leadership. In fact, JCs have not been found to have full capacity to tackle the varieties of issues reported in the JCs (Centre for Investigative Journalism, Nepal, 2019).

The local JCs receive complaints on domestic violence, boundary dispute, family disputes, property, among other issues. Many of the local residents knock on the door of the JC, seeking a solution to the disputes. Among the total of 348 cases lodged in these five municipalities until mid-June 2019, only 146 cases settled while 191 are pending or waiting for justice and 22 forwarded to the courts (Centre for Investigative Journalism, Nepal, 2019). 
A recent study by the Nepal Law Society (NLS) shows that out of total disputes, only around 15 per cent tend to be registered in the proper court and judicial authorities. Though the JCs have the key role in settling disputes through mediation or regular judicial process at the local level, they have not been able to perform as expected due to a lack of capacity, expertise, resources, and human resources. Pradhan (2018) clearly mentioned that due to the lack of separate institutional/administrative mechanisms and the absence of regulations on the LGOA, the JCs lack clarity, institutional capacity, and coherent policy framework.

Conflicts can also arise during and in the aftermath of the COVID-19 pandemic. The recent pandemic has led to prejudicial behaviour towards people belonging to certain ethnic, religious groups or those living in certain geographical locations. It has also led to discrimination and stigmatization of the infected and the health workers involved in patient care. While some of the patients have been denied entry to their homes after being discharged from the hospital, many doctors, nurses have been forced to evacuate their rented living space and even denied services at eateries. In this scenario, besides the public health professionals, the community mediators can solve the various conflicts by providing appropriate information regarding disease transmission, infectivity, methods of prevention, and debunking myths. Based on the trends and developments of the global COVID-19 pandemic, Nepal should carry out activities to address the problems of the COVID crisis in Nepal. The government has emphasized investment in Nepal's health systems regardless of the extent of the COVID-19 pandemic and the effective response to both infected people and affected people.

Pradhan (2018) has emphasized the need for multi-pronged interventions to empower the local JCs to build their capacity to ensure justice delivery for the ordinary people. There is also a need to explore the extent of mediation practiced by the JCs in the urban and rural municipalities while resolving the disputes at the community level. Instead of adopting mediation, if the JCs adopt the strategy of the court to give jurisdiction, it may have adverse effects in ensuring peace at the community level and also on the modes of operating the JC. If the JCs can function effectively, the present structure will provide access and quality of dispute 
resolution to the people. Therefore, there is a need to explore the changing roles of the JCs based on mediation practices and suggesting strategies for building the capacity of the members of JCs in Nepal.

\section{Conclusion}

Many disputants who approach a community mediation program for dispute resolution do so because they know that such a program exists in their community. In Nepal, local organizations and groups such as the paralegal committee or the mother's group also refer cases to mediation programs. In most instances, cases are referred to the mediation program by the respective local VDC or municipality where disputants first register their grievances. Therefore, building the capacity of the members of the JC should be seen not only as an effort to empower women but also to maintain community mediation to ensure peace in the community.

\section{Disclosure Statement}

The author declares that no potential conflict of interest exists.

\section{References}

Adhikari, B., \& Stein, D. (2013).

Community mediation (Policy

Brief).https://bipinadhikari.com.np/

$\underline{w p}-$

content/uploads/2019/02/Communit y-mediation-policy-brief_ESP.pdf

Amos, L., Pandey, A. Shrestha, R, Pandey, A., Bishwokarma, S., \&

Tellery, E.N. (2016). Justice mechanisms and conflict dynamics in Nepal: Local perceptions and impacts. https://gsdrc.org/documentlibrary/justice-mechanisms-andconflict-dynamics-in-nepal-localperceptions-and-impacts/ Barron, P. (2017). Dalits left behind as Nepal slowly recovers. The Asia Foundation.

http://asiafoundation.org/2017/04/19 /dalits-left-behind-nepal-slowlyrecovers/

Berg, H. (2013). Mediation in New

Zealand: Widely accepted and successful.

https://www.researchgate.net/public ation/287336724_Mediation_in_Ne w_Zealand_Widely_Accepted_and Successful

Centre for Investigative Journalism, Nepal. (2020). Journal judicial 
committees: Lack of capacity, expertise, and clarity.

Commission of Investigation on Enforced Disappeared Persons. (2017). Second interim report submitted to the Prime Minister. http://ciedp.gov.np/downloadfile/Se cond\%20Interim\%20Report, \%2020 74_1518669654.pdf

Dahal, D. R., \& Bhatta, C. D. (2008). The relevance of local conflict resolution mechanisms for systemic conflict transformation in Nepal, Berghof Foundation for Peace.

De Voe, P. A., \& Larkin, C. J. (2018). Community mediation as a tool for addressing social exclusion in Nepal.

https://law.wustl.edu/faculty_profile s/documents/larkin/criticalhalfarticle .pdf

Friedrich-Ebert-Stiftung. (2001).

Conflict resolution.

http://www.fesnepal.org/activities/c onflict_resolution.htm

Grange, M. (2014). Community mediation.

https://core.ac.uk/download/pdf/413 38841.pdf

International Crisis Group. (2009).

Nepal's faltering peace process

(Asia report 163-19).

https://d2071 andvip0wj.cloudfront.n et/163-nepal-s-faltering-peaceprocess.pdf

Karki, A., \& Seddon, D. (2003). The people's war in historical context: The people's war in Nepal, left perspective. Adroit.

Keller, D., \& Trevaskis. (1994). Mediation in the schools. ERIC Digest.

Lamsal, H. B. (2012). Role of Dalit civil society against untouchability: Challenges and prospects. Journal of Social Sciences and Public Policy, 75-84.

Lederach, J. P., \& Thapa, P. (2012). The staying true in Nepal: Understanding community mediation through action research occasional paper. The Asia Foundation .

Lee, J. K. (2013). Mediation in main Land China and Hong Kong: Can they learn from each other. City University of Hong Kong. Lee, S. Y. (2011). Dynamics of interplay between third-party interveners and national factions in civil war peace negotiations: case studies on Cambodia and El Salvador [Doctoral thesis, University of St. Andrews].https://researchrepository.standrews.ac.uk/bitstream/handle/100

Social Inquiry: Journal of Social Science Research, Volume2, Issue 2, 2020 
Mediation Practices in Post-Conflict Nepal |299

23/1864/SungYongLeePhDThesis.P

DF;jsessionid=E3AC5452251C779

E896159DCC17B2523?sequence $=6$

Linda, M. (2000). The devil and the deep blue sea? A critique of the ability of community mediation to suppress and facilitate participation in civil life. Journal of Law and Society, 135-36.

Martinelli, D. P., \& Almeida,A. P. (1998).Negotiation, management, and systems thinking.Systemic Practice and Action Research, 11(3).

Merriam Webster. (2019). Webster's dictionary Warner . https://www.merriamwebster.com/dictionary/conflict Mic, E., Mic, V., \& Radulescu, D. (2014). The role of mediation in school.

https://papers.ssrn.com/sol3/papers. cfm?abstract_id=2409041

Ministry of Law, Justice \& Parliamentary Affairs. (2015). Constitution of Nepal 2015.

Murray, B. A. (2003).Examining school based meditation [Unpublished master's thesis]. The Graduate College University of WisconsinStout.

Nepal Law Commission. (2011).

Mediation act, 2068 (2011). http://www.lawcommission.gov.np/ $\underline{\mathrm{np} /}$

Nepal Law Commission. (2017). Local governance act 2074.

www.lawcommission.gov.np

Nepal National Dalit Social Welfare Organization. (n.d.). Historical background.http://www.nndswo.org .np/index.php?page $=$ aboutuscontent\&content_id=3

Office of the High Commissioner for Human Rights. (2012).NepalConflict report 2012.

https://reliefweb.int/sites/reliefweb.i nt/files/resources/OHCHR_ExecSu mm_Nepal_Conflict_report2012.pdf

Pant, S.B. (2019).Dalit women as the mediators in dispute resolution in Kathmandu: Need for building their capacity. Shaishik Smarika 2076 (Special Issue).

Paudel, S. (n.d.). Women's role in peace building in Nepal.

http://www.fesnepal.org/activities/c onflict_resolution.htm

Pradhan, K. M. (2018). Judicial committees: The teething problems. https://thehimalayantimes.com/opini on/judicial-committees-the-teethingproblems/

Read, B. L., \& Michelson, E. (2008). Mediating the mediation debate: Conflict resolution and the local state in China. The Journal of 
Conflict Resolution, 52(5), 737-764. http://www.jstor.org/stable/2763863 6

Ridley-Duff, R. J., \& Bennett, A. J. (2010, September 14-16).Mediation: Developing a theoretical framework to understand alternative dispute resolution[Paper presentation]. British Academy of Management, University of Sheffield.

Sharma, G. (2013). Ex-Maoist fighters join army in Nepal but challenges remain.

https://www.reuters.com/article/usnepal-maoists-army/ex-maoistfighters-join-army-in-nepal-butchallenges-remainidUSBRE97P0H020130826

Silvera, D. (2006). Mediation and its role in adult education.

https://www.mediate.com/articles/sil veraD1.cfm

The Asia Foundation. (2013). Nepal conflict transformation and peacebuilding.

http://asiafoundation.org/where-wework/nepal

Tiwari, B.N. (2007, October 11). An assessment of the causes of conflict in Nepal [Paper presentation]. Second Annual Himalayan Policy Research Conference Nepal Study Centre, Madison .
The Kathmandu Post. (2018). Judicial committees.

http://kathmandupost.ekantipur.com /news/2018-02-07/judicialcommittees.html

The Record. (2018). TRC completes preliminary investigations of less than one percent of cases in three years.

https://www.recordnepal.com/wire/n epal-truth-and-reconciliation/

Truth and Reconciliation Commission. (2014). The enforced disappearances enquiry, Truth and Reconciliation Commission act, 2071 (2014). http://trc.gov.np/wpcontent/uploads/2018/03/actsrulesgu idelines-1.pdf

Upreti, B. R., Sharma, S. R., Pyakuryal, K. N., \& Ghimire, S. (2010). The remake of a state: post-conflict challenges and state building in Nepal. Swiss National Centre of Competence in Research NCCR North .

USAID. (2016). Justice mechanisms and conflict dynamics in Nepal: Local perceptions and impacts. http://www.saferworld.org.uk/oldsit e/resources/view-resource/1069justice-mechanisms-and-conflictdynamics-in-nepal-localperceptions-and-impacts 
Valters, C. (2013). Community mediation and social harmony in Sri Lanka (JSRP Paper 4). Justice and Security Research Programme, International Development Department, London School of Economics and Political Science.

Wall, J. A. (1993). Community mediation in China and Korea: Some similarities and differences. Negotiation Journal, 9(2), 141153.https://doi.org/10.1007/BF0100 $\underline{0552}$
Wall, J. A., \& Blum, M. (1991). Community mediation in the People's Republic of China. Journal of Conflict Resolution, 3-20. Zander, M. (2017). Community mediation[Paper presentation]. Conflict resolution conference. Zhang, S. (2016). Managing in conflict: how actors collaborate in marketing green chemistry. https://theses.gla.ac.uk/7167/1/2016 ZhangPhD.pdf

\section{Author Biosketch}

Sambid Bilas Pant is a peace scholar with a Master's degree in Conflict, Peace and Development Studies, Tribhuvan University. He is a strong media and communication professional with skills in journalism, media relations, and public speaking. He is an independent research writer and has written several articles on mediation practices, education, Nepali art, culture, and people stories. He completed a research fellowship from the Institute of South Asian Studies (ISAS), Sichuan University in China, and conducted research on the high school education system in China. He has also lectured on academic writing and linguistic skills as an IELTS tutor.

To cite this article: Pant, S. B. (2020). Mediation practices in post-conflict situation in Nepal: The way forward. Social Inquiry: Journal of Social Science Research, 2(2), 279-301. https://doi.org/10.3126/sijssr.v2i2.33080

\section{For other articles and journal archive, visit:}

1. http://socialinquiryjournal.org/index.php

2. https://www.nepjol.info/index.php/sijssr/index 